\title{
KABHANTI WUNA MEDIA KOMUNIKASI TRADIOSONAL DAN TANTANGANNYA DI ERA GLOBALISASI
}

\author{
Hardiman \\ Institut Agama Islam Negeri Manado \\ (hardianti@yahoo.co.id) \\ Ardianto \\ Institut Agama Islam Negeri Manado
}

\begin{abstract}
Abtract. On the ethnic communities of Muna at Southeast Sulawesi be known their Wuna kabhanti arts performance. Kabhanti arts performance was not only an expression of the culture, but at the same time were aneducational an media, communication and entertainment. In the field of education, perfomances of kabhanti contributed in the establishment and embedded of noble character. It communicative language make kabhanti's performance arts could be used as a medium of communication, especially as a medium for conveying messages morals, ethics, education, and development. Therefore, on the verge of extinction, continuity and conservation of arts performance of kabhanti needs to be continuously conducted as one of the local culture and local wisdom of ethnic communities of Muna ar Southeast Sulawesi.
\end{abstract}

Key Word: Kabhanti Wuna, Medium of Communication, Traditional, Globalization

Abtrak. Dalam masyarakat etnis Muna di Sulawesi Tenggara dikenal adanya seni pertunjukan kabhanti Wuna. Seni pertujukan kabhanti tidak hanya merupakan suatu ekspresi kebudayaan, tetapi sekaligus media pendidikan, komunikasi, dan hiburan. Dalam bidang pendidkan, pertunjukan kabhanti membantu dalam pembentukan dan penanaman watak yang luhur. Bahasanya yang komunikatif menjadikan seni pertunjukan kabhanti dapat dipakai sebagai sarana komunikasi, khususnya sebagai media penyampaian pesanpesan moral, etika, pendidikan, dan pembangunan. Oleh karena itu, di ambang kepunahannya, pemertahanan dan pelestarian seni pertunjukan kabhanti ini perlu dilakukan 
teus-menerus sebagai salah satu budaya lokal nusantara dan kearifan lokal etnis Muna di Sulawesi Tenggara.

Kata kunci: Kabhanti Wuna, Media Komunikasi, Tradiosonal, Globalisasi

\section{A. Pendahuluan}

Muna adalah salah satu etnis atau suku yang terdapat di Sulawesi Tenggara, tepatnya di Pulau Muna. Sebagaimana etnis lainnya di Indonesia, etnis Muna memiliki keragaman budaya dan tradisi. Salah satu tradisi yang dimiliki oleh masyrakat muna adalah kabhanti Wuna. Kabhanti wuna adalah salah satu seni tradisi lokal dalam bentuk seni pertunjukan. Seni pertunjukan kabhanti ini merupakan media komunikasi tradiosonal pada masyarakat etnis Muna menggunakan bahasa Muna. Bahasa Muna sendiri adalah salah satu entitas bahasa daerah di Sulawesi Tenggara yang merupakan lingua franca bagi masyarakat etnis Muna di Sulawesi Tenggara dan komunitas etnis Muna yang berada di daerah lainnya di Indonesia.

Secara etimologi Kabhanti terdiri atas prefiks ka dan bhanti. Ka sebagai perihal dan bhanti artinya menyindir atau memantun. Kabanthi sebagai salah satu jenis karya sastra berarti syair, puisi, atau nyanyian. ${ }^{1}$ Menurut Niampe, kabhanti berasal dari kata dasar bhanti yang artinya sindir atau senandung. Jadi kabhanti mengandung arti sindiran atau senandungan. Sedangkan, kabhanti Muna adalah perihal menyindir atau memantun dalam bahasa Muna. ${ }^{2}$ Bahasa Muna merupakan pendukung kebudyaan daerah Muna yang sampai sekarang masih di pakai sebagai alat komunikasi bagi masyarakat Muna di kabupaten Muna dan sejumlah pemukiman etnis Muna di daerah lain di Indonesia, seperti di kota kendari, di kota makasar, dan di kota bitung Sulawesi Utara. Di samping sebagai alat komunikasi sehari-hari, bahasa Muna juga berfungsi sebagai media sastra yang diungkapkan dalam pantun, nyanyia, atau pepatah-petitih. ${ }^{3}$

Mokui mengemukakan bahwa dilihat dari penggunaannya, Kabhanti

${ }^{1}$ J.C. Anceaux, Wolio Dictionary (WolioEnglish-Indosian), (Dordrecht-Holland/providenceUSA: Foris Publication Hollad, 1987), h. 51.

${ }^{2}$ La Niampe, Kabanti Oni Wolio (Puisi Berbahasa Wolio), (Jakarta: Departemen Pendidikan dan Kebudayaan, 1999), h. 1.

3 La Ode Sidu Marafad, Semiotika, (Kendari: jurusan Bahasa dan Sastra Indonesia FKIP Universitas Haluuleo, 1997), h. 17 
Wuna terbagi menjadi empat macam, yaitu: kantola, kabhanti, watulea, kabhanti gambuso, dan kabhanti medero. ${ }^{4}$ Kabhanti kantola, yaitu kabhanti yang digunakan pada waktu bermain kantola. Kantolah adalah sejenis prmainan tradiosonal, dimana para pemain berdiri berhadapan antara pemain pria dan wanita. Acara kantola biasanya dilaksanakan pada malam hari di musim kemarau setelah selesai panen ubi kayu dan ubi jalar. Kabhanti watulea adalah kabhanti yang menggunakan irama watulea dan biasanya dinyanikan pada waktu menebang kayu di hutan atau berkebun. Kabhanti gambusu adalah pantun yyang dinyanyikan dengan diiringi irama gambus serta botol kosong yang ditabuh/dipukul dengan sendok atau paku. Kabhanti modero adalah kabhanti ang dinyanyikan pada waktu bermain modero. Modero merupakan tari daerah yang hampir sama dengan tari lulo (tari daerah Sulawesi Tenggara) dan tari dero di Sulawesi Tengah. Para pemain saling bergandengan tangan dengan membentuk lingkaran bernyanyi seirama dengan langkah dalam tarian.

Berdasarkan hasil penelitian kabhanti Wuna yang dilakukan oleh La

${ }^{4}$ La Mokui, kabhanti Wuna, (Raha: PT Astri Jaya, 1991), h. 6-8.
Sudu $^{5}$ dan Samsul, ${ }^{6} \quad$ keduanya memberiakan pendapat yang sama bahwa kabhanti Wuna dalam ambang mengkhawatirkan. La Sudu, misalnya, mengemukakan bahwa keberadaan kabhanti watulea dan kantola sekarang sudah tidak lagi terdengar lagi pada masyrakat Muna, sedangkan modero saat ini juga berada diambang kepunahan. Sekarang ini hanyalah kabhanti gambusu yang masih bertahan. $^{7}$ Lebih lanjut dikatakan bahwa walaupun kabhanti gambusu pada masa sekarang masih dipertunjukan, tetapi tidak seeksis dulu. Dulu apabilah ada pertunjukan kabhanti gambusu, maka para penonton atau pendukung beramai-ramai menyaksikan pertunjukan. Pada masa sekarang setiap pertunjukan kabhanti gambusu ditampilkan, maka penontonnya berkurang.selain itu pula, dewasa ini, pertunjukan kabhanti gambusu mulai jarang digelar. Kehadiran alat hiburan lain

\footnotetext{
${ }^{5}$ La Sudu, "Tradisi Lisan Kabhanti Gambusu pada Masyarakat Muna di SulawesiTenggara (Tinjauan Pewarisan)", Tesis, (Jakarta: Fakultas ilmu Pengetahuan Budaya Universitas Indonesia, 2012)

${ }^{6}$ Samsul "Tradisi Lisan Kabhani Modero pada Masyarakat Muna di Sulawesi Tenggara", Tesis, (Jakarta: Fakultas ilmu Pengetahuan Budaya Universitas Indonesia, 2012)

${ }^{7}$ La Sudu, "Tradisi Lisan..., h.2-3.
} 
yang dianggap moderen telah menggeser posisi yang ditempati kabhanti gambusu. ${ }^{8}$

Era globalisasi yang ditandai dengan perkembangan teknologi yang semakin cepat yang dampaknya ialah pergeseran tata nilai dan struktur budaya dalam masyarakat menjadi salah satu faktor pemicu berkurangnyaminat dan pemahaman generasi muda terhadap kabhanti Wuna. perkembangan tekonologi yang sangat kompleks dan canggi telah mengubah orientasi generasi muda dalam banyak aspek termasuk diantaranya adalah budaya modern yang lebih tersedia di sekitarnya. Dengan demikian semakin menambah kekhawatiran bahwa dimasa mendatang kabhanti Wuna tidak menutup kemungkinan akan punah satu per satu.

Dunia seni pertunjukan saat ini tengah menghadapi gempuran teknologi canggih. Datangnya teknologi lektronik canggih tidak urung akan mempengaruhi gaya hidup dan perilaku manusia dalam melakukan berbagai aktivitas seni. Munculnya teknologi media (rekaman audio dan audio visual) dengan peralatan serba canggih membawa harapan dan sekaligus tantangan bagi dunia seni pertunjukan. Teknologi yang merupakan

\footnotetext{
${ }^{8}$ La Sudu, “Tradisi Lisan..., h. 3
}

bagian dari kebudayaan yang diciptakan manusia, berbalik menimbulkan problem manusia dalam konteks moral dan iman. ${ }^{9}$

Dampak globalisasi menyebabkan kabhanti di Wuna terpuruk. Pengaruh teknologi tontonan yang menyajikan berbagai hiburan yang mudah diakses melalui media elekrtonik menjadikan tontonan seni tradisi termasik pertunjukan kabhanti semakin kurang diminati. Globalisasi adalah proses pengintegrasian ekonomi nasional kepada ekonomi dunia berdasarkan keyakinan pada perdagangan bebas yang berkembang menuju pada dominasi ekonomi, politik, dan budaya. Sistem yang secara ekonomi berwatak eksploitatif, secara politik berwatak repsesif, dan secara budaya berwatak hegemmonik, dan diskursif, dari sebagian kecil elit masyarakat mendominasi rakyat kecil. ${ }^{10}$ Hegemoni budaya di era globalisasi ini melemahkan kultur local sekaligus membangkitkannya kembali. ${ }^{11}$ Lemah

9 Emiliana Mariyah, "Wayang Kulit dalam Era Globalisasi”, dalam pujastawa (ed), Wacana Antropologi, (Denpasar: Jurusan Antropologi Fakultas Sastra Unud, 2006), h. 199

${ }^{10}$ Mansoer Fakih, Runtuhnya Teori Perkembangan dan Globalisasi., (Yogyakarta: Insist Press bekerja sama dengan pustaka Pelajar, 2003), h. 210

${ }^{11}$ Ritzer George dan Douglas J. Goodman, Teori Sosiologi Modern, Edisi Keenam, (Jakarta: Prenada Media, 2004), h. 591. 
karena ia tidak dapat bersaing dengan kultur global yang lebih modern, tetapi pada saat yang sama budaya global memiliki kecenderungan membangkitkan budaya local dalam bentuk transformasi budaya local.

\section{B. Seni Pertunjukan Kabhanti dalam Era}

\section{Globalisasi}

Seni pernjukan kabhanti tidak hanya merupakan suatu ekspresi kebudayaan, tetapi sekaligus media pendidikan, komunikasi, dan hiburan. Seni pertunjukan kabhanti merupakan khazanah kebudayaan masyarakat Muna yang mempunyai kedudukan tersendiri bagi pemiliknya. Dalam bidang pendidikan, pertunjukan kabhanti membantu dalam pembentukan dan penanaman watak yang luhur. Pada hakikatnya semua seni bermaksud untuk dikomunikasikan. ${ }^{12}$ Kominikasi yang disampaikan seni adalah pengalaman yang berharga, yang bermula dari imajinasi kreatif. Seni baru bermakna jika dirinya mengandung kekuatan pesan yang komunikatif. Oleh karena itu, seni pernjukan kabhanti perlu dilestarikan dan dikembangkan terus-menerus sebagai sarana pendidikan di tengah-tengah

\footnotetext{
12 Sumandiyo Y. Hadi, Seni dalam Ritual Agama, (Yogyakarta: Buku Pustaka, 2006), h. 275
}

masyarakat. Kabhanti sebagai media pertukaran informasi dari segi penampilan kabhanti sangat komunikatif dalam pertunjukannya. Berhubung sifatnya sangat komunikatif dapat dipakai sebagai sarana komunikasi, khususnya sebagai media penyampaian pesan-pesan moral, etika, pendidikan, dan pembangunan.

Kemajuan teknologi menyebabkan dunia seakan-akan tidak memiliki batasanbatasan lagi. Sajian hiburan-hiburan masa kini membanjiri dan menghibnotis masyarakat. Kondisi seperti ini membuat tradisi lisan seperti kabhanti mulai terdesak dan kalah bersaing dengan sumber hiburan dan tontonan modern yang lebih menarik karena memanfaatkan media elektronik semakin canggihdan beragam bentuknya, seperti film dan sinetron. Maraknya seni elektronik mau tidak mau, harus dihadapinya dengan jalan meningkatkan daya kreativitas dan melakukan inovasi lainnya sesuai dengan tuntunan zaman. Realitas ini sesuai dengan pendapat Piliang, bahwa budaya local di era globalisasi ekonomi, informasi, dan kultural dewasa ini berada dalam kondisi tarik-menarik dalam kegiatannya terutama jika hal ini diperhadakan pada berbagai tantangan dan pengaruh globalisasi, yang menghadapkannya pada pilihan-pilihan 
yang dilematis. ${ }^{13}$ Di satu pihak menurut Piliang globalisasi dilihat oleh budaya local sebagai sebuah peluang bagi pengembangan potensi diri dan kenggulannya dalam sebuah medan persaingan global yang kompleks, sedangkan diphak lain globalisasi dilihat pula sebagai ancaman terhadap eksistensi dan keberlanjutan budaya local itu sendiri. ${ }^{14}$

Perkembangan era globalisasi memungkinkan terjadinya perubahan pada berbagai bidang, salah satunya adalah tradisi kabhanti. Pada era globalisasi sekarang ini terjadi pergulatan antara nilai-nilai budaya dan tradisi masyarakat local, dengan budaya-budaya luar/asing. Budaya asing luar yang bermaksud adalah negara luar yang diadopsi lewat berbagai media masa. Generasi muda menganggap bahwa budaya luar merupakan budaya modern, sedangkan budaya tradiosonal (kabhanti) merupakan budaya yang kuno. Hal ini mengakibatkan timbulnya pemikiran di kalangan generasi muda bahwa tradisi lisan merupakan produk budaya

${ }^{13}$ Yasraf Amir Piliang, "Menciptakan Keunggulan Lokal untuk Merebut Peluang Global: Sebuah Pendekatan Kultural" Makalah Disajikan dalam Seni dan Desain Institut Seni Indonesia Denpasar,2005, h. 1.

14 Piliang, "Menciptakan..., h. 1. tradiosonal dan karena itu sudah sewajarnya ditinggalkan.

\section{Tantangan Kabhanti di Era Globalisasi}

Tradisi di era globalisasi menghadapi tantangan menuntun pelaku budaya untuk berkreasi dan berinovasi. Hanya saja untuk berinovasi agar tradisi tetap diminati harus mempertimbangkan ruh tradisi bersangkutan. Usaha merupakan jalan terbaik, tetapi perlu diingat bahwa kreasi serta inovasi yang dilakukan harus tetap tidak boleh menghilangkan "ruh" jenis-jenis pertunjukan kesenian tradiosonal yang bersangkutan. Tantangan keberadaan kesenian kabhanti masa ini cukup berat. Karena pada yang sama ia berhadapan dan bersaing dengan jenis kesenian modern maupun kontemporer yang telah banyak tampil bahkan merajai layar kaca (televisi). Para seniman kabhanti sendaknya selalu tanggap terhadap perubahan lingkungannya, sehingga dapat bersaing dengan kebudayaan modern dan kontemporer.

Sampai sekarang kita masih mendengar keluhan bahwa seni tradisi semakin terpinggirkan. Hal ini terjadi karena tidak lain, di satu sisi seni tradisi 
yang selama ini menjadi legitimasi atau symbol bagi bangsa yang beradap, dan di sisi lain tradisi di anggap sakral, me njadi sangat artifisial karena hanya bernilai seni hiburan saja. Bahkan hanya sekedar symbol atau sebagai pernak-pernik kehidupan masa lampau atau peninggalan sejarah kehidupan masyarakat dalam periode lampau, sehingga masyarakat yang hidup di era kekinian sendiri akan merasa kesulitan bagaimana memposisikan seni tradisi dalam dinamika global.

Globalisasi semakin akan semakin kencang berjalan di masa-masa yang akan datang, dan wujud dari proses tersebut kini munculnya berbagai macam hiburan modern dan yang kemasan lebih menarik, yang kemudian menggeser eksistensi budaya-budaya local termasuk kabhanti. Mungkinkah dilakukan pelestarian dalam situasi dan proses globalisasi? Atau masih relevankah upaya pelestarian tersbut?

Bagi pegiat budaya, misalnya, memandang bahwa pelestarian budaya local dipandang sebagai hal yang sangat penting. Demikan pula, generasi tua, misalnya, masih mempunyai sikap positif terhadap tuturan yang terdapat dalam kabhanti. Tradisi kabhanti masih dinilai sebagai baggian dari penanda identitas etnik. Identitas ini dapat diberikan, diperkuat, dilestarikan oleh berbagai macam symbol yang mampu menampilkan identitas tersebut dengan kental, dan tradisi lisan kabhanti adalah salah satu kabhanti di Muna umumnya menggunakan bahasa daerah Muna, sehingga ciri kelokalannya menjadi begitu jelas. Bahasa daerah ini tidak mungkin diganti dengan bahasa lain, jika tidak ingin makna simbolis kabhanti tersebut menipis dan kehilangan kekuatannya membangkitkan emosi. Dan kedua, tradisi lisan kabhnti dipelajai dan disaksiakan dilingkungannya sehingga apa yang ada dalam pertunjuakan kabhanti dapat masuk dengan cepat.

Berkenan dengan proses globalisasi yang kian bertambah kuat mendera seniseni kehidupan masyarakat dewasa ini, kabhanti dapat dipandang sebagai asset budaya dan parawisata, warisan budaya, yang dapat membantu melestariakan jati diri seorang individu, identitas etnik, dan jati diri bangsa. Dalam perspektif inilah tradisi lisan kabhanti sebagai sebuah unsur budaya tetap dianggap penting, memiliki fungsi positif bagi kehidupan seorang individu dan komonitas etnis. Oleh karena itu, sudah sepantasnya tradisi kabhanti dipandang sebagai sebuah warisan masa lalu yang berharga dan perlu dilestarikan keberadaannya. 
Suatu unsur budaya seperti tradisi lisan kabhanti perlu dilestarikan dan dipertahankan keberadaannya, karena tradisi ini merupakan sarana komunikasi tradiosonal, sarana sosialisasi sfektif dari nilai-nilai yang dipandang penting oleh masyarakat. Nilai-nilai ini diinginkan menjadi pedoman hidup, landasan hidup, dan pedoman perperilaku dalam kehidupan sehari-hari warga masyarakat. Oleh karena itu, jika deposit budaya tersebut hilang, hal itu akan berarti pula hilangnya sarana sosialisasi nilai-nilai yang efektif, yang kemudian juga mempengaruhi kelestarian nilai-nilai syarat dengan kearifan.

Lebih dari itu, tradisi lisan kabhanti biasanya juga dapat menjadi arena sosial dan pembelajaran sosial (social learning) bagi masyarakat dalam mengenal dam mempraktikkan kehidupan kolektif dan berbagai bentuk kerja sama untuk mencapai tujuan tertentu, yang penting artinya bagi keberlangsungan hidup berbagai masyarakat. Hilangnya tradisi kabhanti ini akan berarti pula hilangnya arena sosial tersebut, dan hal ini akan mempengaruhi kemampuan individu dalam membangun kehidupan sosial yang harmonis dalam kehidupan sehari-hari.
Memang harus diakui, bahwa ada berbagai kendala yang dihadapi oleh keberadaan seni tradisi termasuk pengaruh industrialisasi. Dengan berkembangnya industrialisasi ini sangat mempengaruhi dan akan berakibat pula terhadap keberadaan seni tradisi yang sudah lama bercokol dimasyarakat pendukungnya. Maraknya kebudayaan massa seperti televise, musik popular, bioskop,kaset atau Video Compact Disc (VCD) dan Digital Versaitle Dics (DVD) yang sudah beriorentasi komersial, selalu bercorak hiburan, tidak rumit, bercirikan modern dan biasanya mengundang jumlah penonton yang relatif banyak. Berbeda dengan seni tradisi yang bercirikan tradiosonal, rumit, lebih kepada seni hiburan (masih ada sedikit sakral) justru hanya mengundang penonton yang sangat sedkit. Inilah tantangan yang harus dihadapi para pelaku seni tradisi termasuk seni tradisi kabhanti pada komunitas etnik Muna.

Dengan demikian, pada zaman yang serba modern ini seni pertunjukan tradiosonal kabhanti menghadapi dua saingan, yaitu (1) seni pertunjukan modern,dan (2) seni pertunjukan masa. Agar tetap bisa bertahan hidup seni pertunjukan tradiosonal harus siap 
bersaing.oleh karena itu, seni tradisi kabhanti harus dikemas lebih kreatif dan inovatif tanpa harus meninggalkan nilai dasar dan kekentalan nlai tradisinya.

Di era global ini, kita semakin prihatin dengan keberadaan anak-anak dan generasi muda yang ternyata sangat rendah minat dan minim pengetahuannnya tentang budaya lokal termasuk kabhanti. Beberapa upaya yang dapat dilakukan untuk meningkatkan minat dan pengetahuan anka-anak dan generasi muda tentang budaya lokal kabhanti. Antara lain: pertama, pengenalan budaya lokal mulai dini, yakni sejak dalam keluarga. Misalnya, orang tua bisa mengajak anak-anak melihat pertunjukan tradisi lisan kabhanti; kedua: pentingnya menyeleksi dan mengevaluasi budaya lokal demi pengembangan masyarakat. Misalnya, pertunjukan tidak terlalu lama, sehingga penontonnya tidak jenuh (pertunjukan kabhanti tidak terlalu suntuk), tetapi bisa diperpendek; ketiga: mengembangkan budaya lokal yang bermanfaat bagi kehidupan masyarakat. Misalnya kabhanti, waktu pertunjukan diperpendek namun misi yang diembannya dapat dipahami penonton; keempat: bahasa yang digunakan harus disesuaikan dengan kondisi zaman yang ada.

\section{Melestarikan Seni Pertunjukan} Kabhanti di Era Globalisasi

Kata "lestari" diartikan tetap seperti keadaan semula, tidak berubah, kekal.15 Dari kata dasar itu membentuk kata melestarikan, pelestarian, dan kelestarian. Melestarikan berarti menjadikan (membiarkan) tetap, tidak berubah, membiarkan tetap seperti keadaannya semula, mempertahankan kelangsungannya. Denga demkian, pelestarian dapat diartikan sebagai pelindung dari kemusnahan atau dari kerusakan, sedangkan kelestrian berarti keadaan yang tetap semula, keadaan semula, keadaan yang tidak berubahubah. ${ }^{16}$ Berdasarkan konsep inilah mencul pengertian pelestarian seni tradisi yang menuntut keasliahan.

Secara leksikal, pengertian pelestarian di atas benar, tetapi yang dimaksud dalam upaya ini tidaklah demikian. Mardimin mengatakan bahwa melestarikan yang diartikan membiarkan

\footnotetext{
${ }^{15}$ Hasan Alwi, et al, Kamus Besar Bahasa Indonesia, (Jakarta: Balai Pustaka 2006),h. 921

16 Johanes Mardimin (ed), Jangan Tangisi Tradisi Transformasi Budaya Menuju Masyarakat Indonesia Modern, (Yogyakarta: Kanisius, 1994), h. 145
} 
tetap tidak berubah, tetapi seperti keadaan semulah, merupakan pelestarian yang mati. ${ }^{17}$ Tafsiran ini mungkin akan lebih tetap jika dipakai dalam arti pelestarian benda-benda mati, seperti benda-benda pusaka ataupun candi-candi.

Pada hal menurut Mardimin, seni tradisi bukanlah benda mati. ${ }^{18}$ Lebih jauh dijelaskan bahwa seni tradisi, secara kronologis selalu berubah untuk mencapai tahap mantap menurut tata nilai hidup pada zamannya. Dengan demikian, seniman dituntut untuk selalu pandai menyesuaikan diri. Pelestarian seni tradisi mempunyai keharusan untuk mempertahankan seperti semula. Perubahan sebagai arahan tidak berarti merombak, melainkan membenahi salah satu atau beberapa bagian yang dirasa tidak memenuhi selera masa kini. ${ }^{19}$

Pelestarian tradisi kabhanti adalah upaya pengabdian, penuturan, dan penyebarluaskan kabhanti antar generasi atau satu sesame generasi secara lisan atau dengan cara lain. Sukatman mengatakan bahwa:

Setiap kelompok tradisi lisan mempunyai perbedaan kekuatan dalam

\footnotetext{
${ }^{17}$ Mardimin (ed), Jangan Tangisi..., h. 146

18 Mardimin (ed), Jangan Tangisi..., h. 146

19 Mardimin (ed), Jangan Tangisi... h. 146
}

mempertahankan hidup dan mengembangkan dirinya sehingga menuntut hubungan yang mapan bagi para pemiliknya. Untuk itu, semua pewaris tradisi lisan perlu kerja sama dalam menyebarkan ke daerah lain, ke jenis kelamin lain, ke etnis, dan ke kelompok umur tertentu. Untuk menyebarkan cerita ini dan bentuk-bentuk penutaran lainnya diperlukan komunikasi tatap muka, pergerakan, dan perjalanan masyarakat dari daerah ke daerah lain. ${ }^{20}$

Lebih lanjut dikemukakan Sukatman bahwa teknologi komunikasi berkembang sangat pesat. Perkembangan teknologi komunikasi yang sangat cepat itu telah mengubah cara berpikir dan berperilaku, serta memapankan kontak sosial dengan alat komunikasi baru. Surat kabar, radio, dan televise masuk ke dunia komunikasi dan menggantikan transmisi lisan dalam produksi budaya. ${ }^{21}$

Kabhanti sebagai jenis tradisi lisan menggunakan tuturan yang dituturkan dan ditransformasikan secara lisan dari generasi ke generasi lewat pelantunan profesionalnya, dan masyarakat setempat

${ }^{20}$ Sukatman, Teka-Teki Jawa sebagai Warga Tradisi Lisan Dunia Konteks, Ideologi, dan Fungsinya dalam Masyarakat Modern, (Yogyakarta: LaksBang PRESSindo, 2010), h. 18

${ }^{21}$ Sukatman, Teka-Teki ..., h. 19 
yang fasih dengan tuturan kabhanti. Dalam masyarakat etnik Muna saat ini tradisi lisan kabhanti banyak dituturkan generasi tua saja, sedangkan generasi muda sudah jarang mempelajarinya.

Persoalan kurangnya minat generasi muda terhadap kabhanti menjadi tantangan tersendiri bagi seniman untuk menarik minat generasi muda mempelajari kabhanti. Untuk membangkitkan minat generasi muda terhadap tradisi pertunjakan lisan kabhanti diperlukan transformasi terhadap seni pertunjukan kabhanti tersebut yang direlevansikan dengan kondisi kekinian yang sesuai karateristik kehidupan masyarakat saat ini. Hanya saja, mengenai hal ini diperlukan kehati-hatian agar tidak terjebak pada pengebirian eksistensinilai tradisi lokal. Tawaran yang lebih humanisadalah melakukan transformasi tanpa meninggalkan spirit kebudayaan bersangkutan.

Terkait dengan problematika dan transformasi tradisi secara umum, Mardimin mengatakan bahwa:

"Tradisi bukanlah objek yang mati. Ia adalah alat yang hidup untuk melayani manusia yang hidup pula. Memang, hanya dalam rentangan waktu yang panjang kita baru dapat memahami dan menunjukan bahwa tradisi sebenrnya juga berubah dan berkembang untuk mencapai tahap mantap pada zamannya. Tradisi diciptakan manusia untuk kepentingan hidupnya. Oleh karena itu, tradisi harusnya dikembangkan sesuai dengan kehidupan. Untuk itu, kita sebagai ahli waris kebudayaan selalu dituntut untuk berani mengadakan perubahan-perubahan terhadap tradisi, membenahi satu atau beberapa bagian yang dirasa tidak sesuai dengan masa kini. Jadi, kita dituntut untuk tidak sekedar mengulang, tetapi mesti "secara baru" memberi wujud baru dengan cara mentransformasikan". ${ }^{22}$

Lebih lanjut, Mardimin mengatakan bahwa tujuan transformasi budaya adalah untuk mencapai masa depan yang lebih baik dengan memperbaiki budaya masa kini. ${ }^{23}$ Hal itu sejalan dengan pandangan Lubis, hari ini adalah masa depan hari kemarin dan hari ini adalah kemarinnya hari esok. ${ }^{24}$ Semuanya saling berkaitan dan kita harus melihatnya sebagai suatu proses yang berkesinambungan. Dan,

${ }^{22}$ Mardimin (ed), Jangan Tangisi ..., h. 13

23 Mardimin (ed), Jangan Tangisi ..., h. 15

24 Mochtar Lubis, Transformasi Budaya untuk Masa Depan, (Jakarta: Inti Idayu Pres, 1985), h. vii 
transformasi adalah cara yang paling tepat untuk mencapai cita-cita itu. 25

\section{E. Pelestarian Pertunjukan Kabhanti:}

\section{Bagaimana dan Untuk Apa?}

Perubahan masyarakat dan budaya adalah suatu hal yang sangat alami dan tidak munkin dicegah prosesnya. Fakta empirisnya bahwa berbagai hal yang mempercepat memudarnya pertunjukan kabhanti dalam masyarakat Muna sekarang adalah kondisi dan perubahan yang tidak mungkin dihindari, kecuali jika memang ada perhatian, perencanaan, serta tindakan yang serius untuk mempertahankan berbagai bentuk kabhanti di Muna dengan memberikan perhatian yang serius. Mungkinkan dilakukan pelestarian dalam situasi dan kondisi proses globalisasi saat ini. Atau masih perlukah upaya pelestarian tersebut.

Bagi sebagian orang (baca generasi tua) Muna, pelestarian suatu unsur tradisi yang dikenal dan angkrab dipandang sebagai hal yang sangat penting. Masalah seni pertunjukan sudah ditinggalkan masyarakat pendukungnya. Dalam kaitan dengan ini, Supanggah mengatakan bahwa (1) seni pertunjukan tersebut mungkin

\footnotetext{
25 Mardimin (ed), Jangan Tangisi ..., h. 15.
}

sudah semakin kehilangan fungsi atau gunanya dimasyarakat akibat beberapa upacara, event atau kegiatan kain yang biasanya menggunakan jasa kesenian tersebut, (2) sering pula keseniankesenian tersebut mulai kehilangan nilai/maknanya karena adanya perubahan pola hidup, nilai yang diberlakukan dimasyarakatnya, (3) adanya gap komunikasi menyangkut penggunaan bahasa verbal serta bahasa ungkap (bahasa arkais) yang disampaikan melalui elemen-elemen kesenian tersebut tidak dipahami masyarakat pada umumnya, dan (4) mungkin juga karena wujudnya sudah berkurang menarik lantaran adanya pergeseran selera masyarakat. ${ }^{26}$

Seni pertunjukan di era globalisasi untuk dapat bersaing dengan budaya lokal harus mampu mereformasi dan merevitalisasi dirinya. Beberapa cara yang dapat ditempuh untuk merevitalisasi adalah (1) refungsionalisasi (memberi fungsi/kegunaan yang baru), (2) reformasi (mengubah bentuk, wujud atau kemasan untuk dapat memenuhi selera sesuai dengan selera zaman), (3) rekreasi (menciptakan karya bau dengan bentuk

${ }^{26}$ Rahayu Supanggah, "Seni Pertunjukan Indonesia Menyambut Industri (Ekonomi) Kreatif”, dalam Industri Budaya, Budaya Industri, (Jakarta: Kemen Kedudpar RI, 2008), h. 355-356 
dan/atau genre atau mengunakan elemenelemen kesenian lama, temasuk nilai-nilai dengan pemaknaannya yang baru, dan (4) reorientasi baru, sehubungan dengan kepentingan dan kebutuhan para konsumennya yang situasi, kondisi, orientasinya juga berubah, semakin berkembang serta majemuk, menurut tempat (lokasi atau ruang) dan waktu (jam, date, maupun durasi) kapan seni pertunjukan disajikan. ${ }^{27}$

Perubahan kebudayaan dan masyarakat adalah hal yang sngat alami dan tidak mungkin dicegah prosesnya. Langkah pelestarian kabhanti di Muna dapat ditempuh melalui dua cara, yakni cara statis dan cara dinamis. Pelestarian suatu unsur budaya termasuk tradisi lisan kabhanti yang dikhawatirkan akan mulai kehilangan generasi pewarisya. Salah satu cara yang relatif mudah namun sekaligus juga akan banyak manfaatnya adalah dengan melakukan identifikasi dan dokumentasi. Identifikasi perlu dilakukan untuk mengetahui jenis unsur-unsur budaya yang masih ada.

Cara pelestarian dinamis dapat dilakukan dengan mengajarkan kepada generasi muda bagaimana pertunjukan

27 Supanggah, "Seni...., h. 356. kabhanti. Jika teknik dan syair kabhanti telah dipahami oleh sejumlah orang atau kelompok, sebuah lomba atau festival dapat diselenggarakan sebagai arena untuk memamerkan kemampuan individu atau sebuah kelompok mempertunjukan kemampuannya.

Pelestarian seni merupakan amanat Undang-Undang Dasar 1945 beserta penjelasannya melalui konsep "pelestarian" yaitu upaya mempertahankan eksistensi, tetapi bukn dalam pengertian statis (mempertahankan sebagaimana aslinya), tetapi dalam pengertian dinamis (selalu menyesuaikan dengan perkembangan peradaban). Dalam termonologi pelestarian, tedapat upayaupaya perlindungan, pengembangan, dan pemanfaatan. Substansi istilah perlindngan, pengembangan, dan pemanfaatan konteks pemeliaharaan budaya disini bermakna:

Pertama, perlindungan adalah upaya menjaga keaslian seni pertunjukan Indonesia dari unsur-unsur budaya asiang dan penyimpangan dalam pemanfaatannya. Upaya ini dilakukan agar tidak mengalami kepunahan, tidak terjadi pendangkalan nilai, tidak merendahkan harkat dan martabat, tidak terjadi penyalagunaan hak. 
Kedua, pengembangan adalah peningkatan kualias dan kuantitas seni seni pertunjukan tradisi yang hidup di tengah-tengah masyarakat tanpa mengilangkan nilai-nilai yang terkandung didalamnya. Upaya untuk menyebarluaskan khazanah seni budaya yang ada dalam bentuk, jenis, tampilan/kemasan.

Ketiga, pemanfaatan adalah pemberdayaan seni budaya untuk pemenuhan kebutuhan batin masyarakat dalam event yang bersifat sakral maupun profan. Upaya pendayagunaan seni budaya bagi kepentingan pendidikan, agama, politik, ekonomi, dan parawisata.

\section{F. Kesimpulan}

Berdasarkan uraian diatas dapat disimpulkan bahwa kondisi-kondisi masyarakat yang berubah telah membuat tradisi lisan kabhanti Muna mulai kurang dikenal. Selain itu, kabhanti Wuna sebagai salah satu jenis seni tradisi pada masyarakat etnis Muna semakinjarang dipertunjukan. Fenomena ini telah membangkitkan keprihatinan pada beberapa kalangan warga masyarakat serta mendorong munculnya upaya-upaya untuk melestarikan tradisi kabhanti Muna.

Di pihak lain, beberapa kalangan malah menyangsikan manfaat upaya- upaya pelestarian tradisi kabhanti wuna sebagai salah satu budaya lokal di Muna, karena kepunahan kabhanti wuna dipandang sebagai upaya poses akibat tejadinya perubahan dalam masyarakat dan kebudayaan. Upaya pelestarian lantas ditafsirkan sebagai upaya-upaya untuk memperlambat proses perubahan tersebut, dan ini dianggap tidak realistis. Meskipun demikian, upaya-upaya lain yang ditunjukan untuk menghasilkan sebuahsintesa yang wajar antar unsur budaya lama dengan unsur budaya baru yang berkembang di tengah masyarakat mulai tumbuh saat ini. Pada konteks inilah upaya pelestarian tradisi kabhanti wuna yang adalah salah satu media komunikasi tradiosonal bagi masyarakat etnis Muna di Sulawesi Tenggara diperoleh momentumnya yang tepat. Pada konteks inilah dibutuhkan kehadiran peran formal pemerintah daerah dalam membuat kebijakan yang pro terhadap upaya pelestarian seni tradisi. Sementara, di pihak masyarakat melalui jalur nonformal dapat bekontribusi untuk ikut serta melakukan langkah-langkah pelestarian budaya lokal dengan menggiatkan kegiatan-kegiatan seni tradisi.

Agar upaya pelestarian tradisi kabhanti dan tradisi lokal lainnya dapat 
berlangsung dengan baik, langkah strategis dan realistis yang dapat dilakukan adalah menelaah kembali keberadaan tradisi lokal yang ada termasuk kabhanti wuna dan mengupayakan pengembangan dan pelestariannya untuk pewarisan nilai-nilai sosial dan budaya yang relevan dengan kondisi kehidupan masyarakat dewasa ini.

\section{Daftar Pustaka}

Alwi, Hasan, dkk. 2006. Kamus Besar Bahasa Indonesia. Cetakan Ketiga. Jakarta: Balai Pustaka.

Anceaux, J.C. 1987. Wolio Dictionory (Wolio -English-Indonesia), Dordrecht-Holland/ProvidenceUSA: publication Holland

Fakih, Mansoer. 2003. Runtuhnya Teori Pengembangan dan Globalisasi Yogyakarta: Insist Press bekerja sama dengan Pustaka Pelajar.

Lubis, Mochtar, 1985. Transformasi Budaya untuk Masa Depan. Jakarta: Inti Idayu Press.

Marafad, La Ode Sidu. 1997. Semiotika. Kendari: Jurusan Bahasa dan Sastra Indonesia FKIP Univesitas Haluuleo.

Mardimin, Johanes (ed), 1994. Jangan Tangisi Tradisi Transformasi Budaya Menuju Masyarakat Indonesia Modern. Yogyakarta: Kanisius.

Mariyah, Emiliana. 2006. "Wayang Kulit dalam Era Globalisasi", dalam
Pujaastawa (ed), Wacana Antropologi. Denpasar: Jurusan Antropologi Fakultas Sastra Unud

Mokui, La. 1991. Kabhanti Wuna.Raha. PT Astri Jaya.

Niampe, La et al. 1991. Kabhanti Oni Wolio (Puisi Berbahasa Wolio). Jakarta: Depertemen Pendidikan dan Kebudayaan.

Piliang, Yasraf Amir. 2005. "Menciptakan Keunggulan Lokal untuk Merebut Peluang Global: Sebuah Pendekatan Kultural". Makalah Disajikan dalam Seni dan Desain Institut Seni Indonesia, Denpasar

Ritzer, George dan Douglas J. Goodman, 2004. Teori Sosiologi Modern.Edisi Keenam. Jakarta: Prenada Media

Samsul. 2012. "Tradisi Kabhanti Modero pada Masyarakat Muna di Sulawesi Tenggara. Tesis. Depok: Fak. Ilmu Pengetahuan Budaya, UI

Sudu, La. 2012. "Tradisi Lisan Kabhanti Gambusu pada Masyarakat Muna di Sulawesi Tenggara (Tinjauan Pewarisan). Tesis. Depok: Fak. Ilmu Pengetahuan Budaya, UI

Sukatman, 2010. Teka-Teki Jawa sebagai Warga Tradisi Lisan Dunia Konteks, Ideologi, dan Fungsinya dalam Masyarakat Modern. Yogyakarta: LaksBang PRESSindo.

Supanggah, Rahayu. 2008. "Seni Pertunjukan Indonesia Menyambut Industri. Jakarta: Kemen Kedudpar RI. 